\title{
Long-term bedload mobility in gravel-bed rivers using iron slag as a tracer
}

\section{Geomorphology 126 (2011) 233-244}

\author{
G. Houbrechts*, Y. Levecq, V. Vanderheyden, F. Petit
}

University of Liège, Department of Geography, Laboratory of Hydrography and Fluvial Geomorphology, B-4000 Sart-Tilman, Belgium. *Corresponding author. Tel.: +32 436652 57; Fax: +32 436657 22; E-mail: G.Houbrechts@ulg.ac.be

\begin{abstract}
Bedload dispersion is evaluated in gravel-bed rivers using slag elements from ironworks established along rivers in the Ardenne region, between the fourteenth and the nineteenth centuries. Large quantities of slag were dumped close to these rivers or even directly into the channels. For centuries, slag elements were dispersed in the bedload and transported by floods of varying importance. Consequently, slag may be considered as a reliable tracer to analyze bedload dispersion over several centuries. The size of slag elements was studied along 16 Ardenne rivers. The longitudinal size trend of the largest slag particles allows the effective competence of these rivers to be determined (between 19 and $129 \mathrm{~mm}$ for rivers where specific stream power for the bankfull discharge ranges between 20 and $134 \mathrm{~W} / \mathrm{m}^{2}$ ). A direct relationship doesn't exist between these two parameters as the size of slag elements must be considered with regard to the $D_{50}$ of the bed. Selective transport was analyzed directly downstream of the input sites. The sorting distance varies from river to river and depends on the velocity of the coarse elements introduced into the river since the inception of the iron industry. Downstream of two metallurgic sites, the slag propagation fronts were located. As the periods of activity at these sites are known from historical studies, the virtual velocity of bedload movement in these rivers was estimated to be $2-4 \mathrm{~km} /$ century.
\end{abstract}

Keywords: gravel transport; slag; effective competence; downstream fining; bedload velocity

\section{Introduction}

Different methods are frequently used to evaluate gravel entrainment (Kondolf et al., 2003). The size and travel distance of mobilized grains can be estimated using painted pebbles (Leopold et al., 1966; Billi, 1988; Petit et al., 2005a), tracers containing iron or magnets (Hassan, 1990; Schmidt and Ergenzinger, 1992; Gintz et al., 1996; Ferguson et al., 2002), PIT-tag (Lamarre et al., 2005; Rollet et al., 2008) or active (radio) tracers (Ergenzinger et al., 1989; Busskamp and Hasholt, 1996; MacNamara and Borden, 2004). These methods evaluate bedload mobility over a relatively short timescale. Furthermore, the results are based on the displacement of isolated elements. These observations are therefore difficult to extrapolate to the whole bedload over a longer period, because of the progressive burying of particles in the subsurface layer (Schick et al., 1987) or because of particles becoming trapped in fluvial forms (point bars, riffles, etc) that can immobilize elements for long periods (Kondolf and Matthews, 1986). Moreover, the virtual velocity of bedload can only be obtained by analyzing the mobilization of elements over a period that is long enough to include mobilization events of various recurrences.

Long-term bedload dispersion has not been widely investigated, and the studies that have been conducted generally employ indirect means: Tricart and Vogt (1967) and Duchesne and Pissart (1985) used sedimentological methods on the Hérault and the Ourthe rivers, respectively. Using old cartographical documents, Salvador (1991) reconstructed the propagation of the Isère River metamorphosis in response to the Little Ice Age climatic cooling. Thevenet et al. (2003) and Liébault et al. (2005) studied the propagation of incision of several streams in the Drôme catchment (southern French Prealps) using tree-ring dating of stabilized alluvial deposits. Their measurements allowed the velocity of the incision front to be determined in connection with the reduction of sedimentary supply from the hillslopes. 
This study analyzes bedload transit by indirect means, studying the longitudinal dispersion of slag elements in the beds of several gravel-bed rivers of the Ardenne massif. Slag was produced by ironworks established along these rivers from the fourteenth century onward (Leboutte, 1979). These waste products were piled onto the floodplains and frequently dumped directly into the rivers (Houbrechts and Weber, 2007). For centuries, large quantities of slag have been incorporated in the bed-material by bank erosion and then transported by floods.

Slag elements are a reliable tracer for studying long-term bedload mobility. They can be compared to thousands of tracers injected into the rivers several centuries ago. Since that time, they have been subject to the same hydrological and trapping conditions as the natural bedload. Downstream of ironworks, slag particles have been mobilized over several kilometers. Locating the propagation front allows us to determine the maximum distance covered by the slag elements from the dumping site. Historical studies of ancient ironworks have established when activity began at these sites, and therefore early slag disposal can be dated. With this data, the virtual velocity of bedload may be estimated (Sluse and Petit, 1998; Houbrechts and Petit, 2003).

Further information on the longitudinal sorting of the bedload can be obtained by analyzing the size of slag elements transported by the river. A sorting reach is systematically observed directly downstream of the input sites. This is followed by a reach where the slag size is relatively constant over several kilometers. The sorting reaches provide information about the mobilization of the bed material and therefore about the transport of the largest grain size classes of the bedload. The reaches with a constant size for the largest slag elements (plateau reaches) allow the river's effective competence to be estimated (Petit, 1987). The effective competence corresponds to the size of the largest pebbles able to move across riffles and to cover quite large distances over a period encompassing floods of varying magnitude (Bravard and Petit, 2000).

These two reaches - the sorting reach and the plateau reach - can be defined by exponential type equations, according to the methodology developed by Werritty (1992). Different equation exponents allow the slag downstream fining (or the bedload downstream fining) to be compared to rivers with different dynamic conditions and different rock types.

Our observations indicate that the size of the largest slag particles transported by the rivers is linked to the specific stream power at the bankfull discharge, as this parameter is a good indicator of a river's competence (Houbrechts and Petit, 2003). Nevertheless, as demonstrated by Ferguson (2005) and Gob et al. (2010), the particle size relative to the riverbed material $\left(D_{i} / D_{50}\right)$ must be taken into account because this factor has an influen ce on the critical thresholds for bedload transport.

\section{Characteristics of the studied rivers}

This paper presents results of bedload mobility for sixteen gravel-bed rivers belonging to the Meuse catchment and located in different geomorphological regions of the Ardenne. All of these rivers contain quite large amounts of slag in their bed material. The longitudinal evolution of the slag size is presented in detail for only two of these rivers (the Rulles and the Viroin) as slag injection sites are solely situated in the upstream part of their catchments. This allows the slag dispersion to be observed over a long distance downstream of the last slag injection site. Meanwhile, in the other rivers, ironworks are spread along the watercourse and the distance between the ironworks is generally short. Consequently, the slag propagation front of each injection can not be located. Nevertheless, the slag size between the injection sites is used in this paper to analyze the effective competence in relation to the specific stream power. 
The riverbed material of these rivers consists of gravels of different lithologies, all from the Devonian period: schist, sandstone, limestone, and quartzite particles (Duchesne \& Pissart, 1985). This material is relatively coarse (Table 1 ), as most of it dates back to the last cold period (Juvigné, 1979). During this period, due of the production of vast quantities of sediment under periglacial conditions, gravel and boulders accumulated on the valley floors in layers that were several meters thick (Houbrechts, 2005). The rivers probably incised through these deposits during the Late Glacial Period (Vandenberghe, 1995, 2008). They reworked the upper part of the gravel sheet during the Holocene, frequently leading to paving development.

The studied rivers have slopes varying from $3.7 \%$ for headwater streams to less than $0.1 \%$ for larger rivers (Table 1). The smallest rivers have catchment areas smaller than $10 \mathrm{~km}^{2}$ while the largest one covers almost $3000 \mathrm{~km}^{2}$.

All of the rivers are equipped with one or several gauging stations where the bankfull discharge was measured (Petit \& Pauquet, 1997; Petit et al., 2005b). Based on these observations, a relationship was established between the bankfull discharge $\left(Q_{b}\right.$ in $\left.\mathrm{m}^{3} / \mathrm{s}\right)$ and the catchment area $\left(A\right.$ in $\left.\mathrm{km}^{2}\right)$. This relationship was then used to estimate $Q_{b}$ in reaches without gauging stations:

$\mathrm{Q}_{b}=0.128 A^{0.981}\left(\mathrm{R}^{2}=0.96 ; \mathrm{n}=38\right)$

Using these parameters, the specific stream power at the bankfull discharge $\left(Q_{b}\right)$ was estimated in the studied reaches using the following equation:

$\omega_{Q b}=\rho g Q_{b} S / w_{b}$

where $\rho$ corresponds to the density of water, $Q_{b}$ the bankfull discharge, $S$ the water surface gradient, and $w_{b}$ the river width at the bankfull stage.

Values of $\omega_{\mathrm{Qb}}$ range from 27 to $134 \mathrm{~W} / \mathrm{m}^{2}$ for the studied rivers (Table 1). Specific stream powers can also vary considerably along an individual river, mostly because of local slope and discharge variation (Knighton, 1999). 
Table 1: Minimal and maximal values of sedimentological, morphological and hydrological parameters measured in the sectors where slag was used. The upstream and downstream limits of the investigated sectors are defined by the size of the catchment area.

\begin{tabular}{|c|c|c|c|c|c|c|c|}
\hline & & $\begin{array}{c}\text { Drainage area } \\
\left(\mathrm{km}^{2}\right)\end{array}$ & $\begin{array}{l}\mathrm{D}_{50} \\
(\mathrm{~mm})\end{array}$ & $\begin{array}{l}\mathrm{D}_{90} \\
(\mathrm{~mm})\end{array}$ & $\begin{array}{c}\text { Slope } \\
(\%)\end{array}$ & $\begin{array}{l}\mathrm{W}_{\mathrm{b}} \\
(\mathrm{m})\end{array}$ & $\begin{array}{c}\omega_{\mathrm{b}} \\
\left(\mathrm{W} / \mathrm{m}^{2}\right)\end{array}$ \\
\hline 1 & Ourthe & $1169-2913$ & $44-86$ & $78-150$ & $0.13-0.16$ & $23-62$ & $54-88$ \\
\hline 2 & Lembrée & $11.4-51.8$ & $56-110$ & $130-300$ & $0.93-2.12$ & $5.7-9.5$ & $53-59$ \\
\hline 3 & Aisne & $63.2-161$ & $70-100$ & $150-230$ & $0.53-0.93$ & $7.5-13.6$ & $72-111$ \\
\hline 4 & R. Vieux Fourneau & $5.7-20.6$ & $55-83$ & $98-240$ & $1.63-3.72$ & $2.9-5.2$ & $45-98$ \\
\hline 5 & Somme & $27.7-37.7$ & $18-70$ & $30-165$ & $0.52-0.80$ & $5.8-7.6$ & $30-41$ \\
\hline 6 & Amblève & $951-1072$ & $99-128$ & $138-200$ & $0.20-0.47$ & $32.9-39.3$ & $61-112$ \\
\hline 7 & Lienne & $103.9-148.3$ & $74-108$ & $145-250$ & $0.64-0.85$ & $7.1-10.7$ & $99-134$ \\
\hline 8 & Chavanne & $7.8-21.2$ & $40-112$ & $79-260$ & $1.10-2.10$ & $2.6-5.4$ & $39-96$ \\
\hline 9 & Semois & $368-415$ & 18 & 49 & $0.10^{\mathrm{a}}$ & $18.6^{a}$ & $27^{a}$ \\
\hline 10 & Rulles & $98.4-220.4$ & $36-72$ & $69-130$ & $0.16-0.32$ & $9.1-12.3$ & $27-30$ \\
\hline 11 & Mellier & $59.3-64.8$ & 39 & 72 & $0.29^{a}$ & $8.1^{a}$ & $36^{a}$ \\
\hline 12 & R. des Epioux & $9.6-12.3$ & $49-61$ & $143-149$ & $2-2.5$ & $3.7-5.9$ & 62 \\
\hline 13 & Vierre & $30-264$ & $31-53$ & $57-99$ & $0.15-0.71$ & $6.4-12.5$ & $40-46$ \\
\hline 14 & R. de Saint-Jean & $31.1-42.2$ & 105 & 170 & 1.5 & 5.3 & 120 \\
\hline 15 & Eau Noire & $73.7-225.5$ & $56-95$ & $85-152$ & $0.30-0.65$ & $11.1-14.1$ & $36-61$ \\
\hline 16 & Viroin & $478.2-594.4$ & $28-78$ & $46-124$ & $0.12-0.22$ & $18.8-21.1$ & $36-64$ \\
\hline
\end{tabular}

${ }^{\mathrm{a}}$ Sluse and Petit, 1998.

Detailed results are presented for two rivers, the Rulles and the Viroin. On both of these rivers, ironworks were located at the head of the catchment, and activity at these sites ceased a long time ago. As a result, slag propagation can be studied over relatively long distances for these rivers.

\subsection{Rulles River}

In its upper catchment, the Rulles River incises through the southern side of the Ardenne massif. Between "La Trapperie" and its confluence with the Mellier River (Fig. 1), the Rulles flows along the contact zone between the Ardenne substratum (Paleozoic rocks) and the Lorraine substratum (Mesozoic rocks) and is joined by several tributaries originating in the Ardenne region (Ruisseau du Fourneau, Mandebras, Mellier). The Rulles then enters the Lorraine region and, after $34 \mathrm{~km}$, joins the Semois River.

About 10 ironworks operated on the Rulles and its tributaries (Bourguignon, 1926-1927; de Moreau de Gerbehaye, 1987-1988; Feltz and Incourt, 1995). Metalworking began in the valley after $A D$ 1540, i.e., later than in the northern part of the Ardenne region (Pirotte, 1967; Gillard, 1971). The ironworks in the Rulles valley were active for several centuries, and they were closed in the mid-nineteenth century. 
Five ironworks were active on the Rulles upstream of the "La Trapperie" blast furnace, which was created in AD 1613. However, large dams linked to the ironworking industry along the river were built upstream of "La Trapperie", trapping bedload transit. Slag particles collected downstream of "La Trapperie", therefore, cannot come from upstream. The same restriction characterizes slag found on the Mellier River: slag produced by the Mellier-Haut ironworks is trapped by the artificial dam at Mellier-Bas.

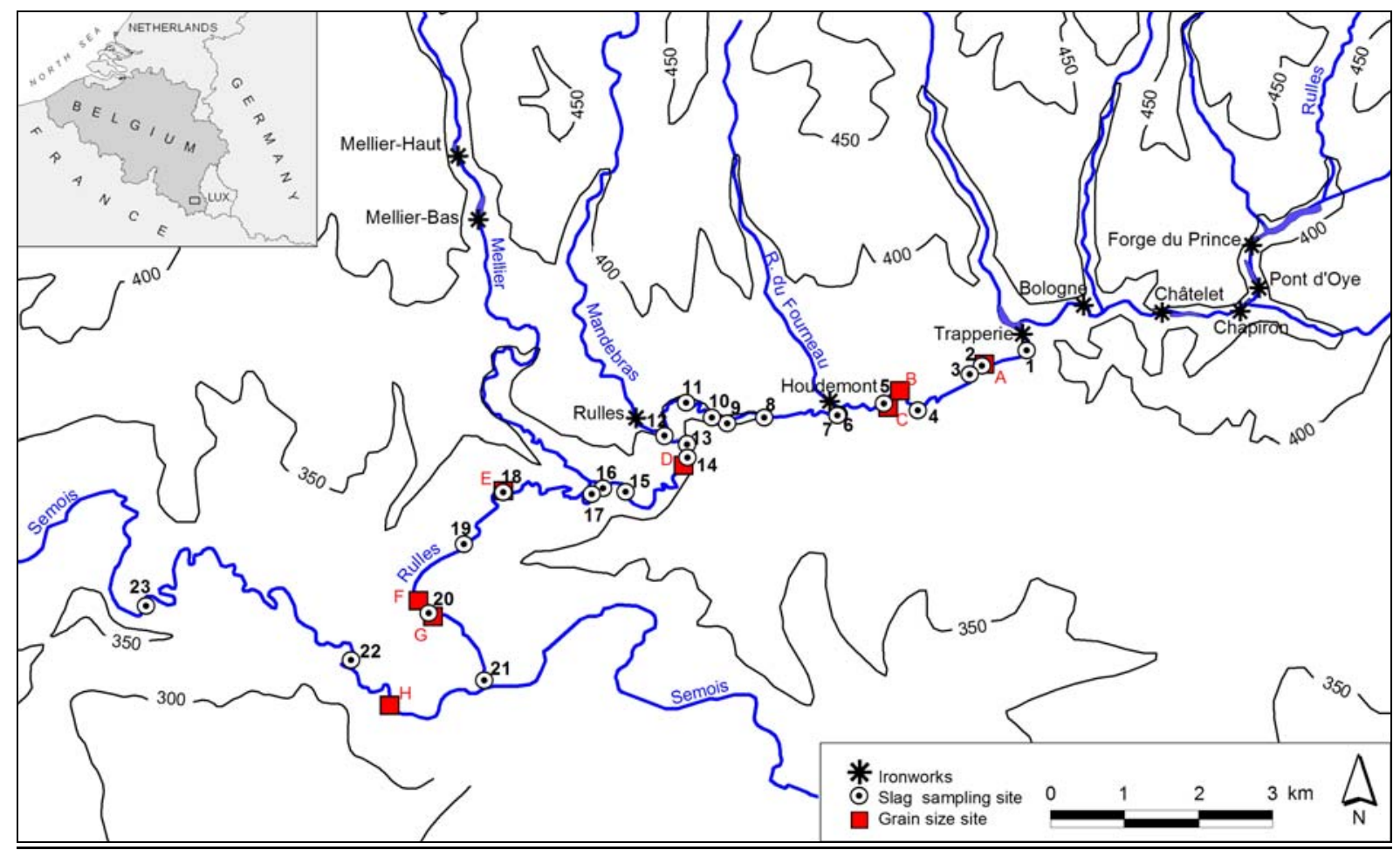

Figure 1: Location map of the Rulles River showing the study reach, the ironworks, the slag sampling sites (sites 1-23) and the riffles where grain size have been determined (sites $A-H$ ).

\subsection{Viroin River}

At its source, the Eau Noire River flows on Cambrian rocks of the Rocroi massif. Downstream, the river crosses Early Devonian substratum down to Couvin, and then flows through a region of Middle and Late Devonian schist and limestone. In this section, part of the runoff disappears through karst fissures and sinkholes, reemerging in Nismes after having covered about $3 \mathrm{~km}$ underground. The Eau Noire River meets the Eau Blanche River $2 \mathrm{~km}$ farther downstream. From the confluence on, it is called the Viroin River (Fig. 2). The bedload of the Eau Blanche is mainly composed of Late Devonian schist pebbles that are relatively small compared to the size of the Eau Noire bedload (Vanderheyden, 2003). After the confluence, the Viroin flows firstly over Middle and Late Devonian limestone and then across Middle Devonian schist down to its confluence with the Meuse River. At this confluence, the Viroin catchment area is $594 \mathrm{~km}^{2}$.

About 30 ironworks were in operation in the Viroin catchment between the early fifteenth and the nineteenth centuries (Gillard, 1971; Allard, 1979; Evrard, 1956). Analysis of slag dispersion was mostly carried out in the Eau Noire River downstream of Couvin and in the Viroin River down to its confluence with the Meuse River (Fig. 2). These reaches were selected in preference to other reaches farther upstream where ironworking sites were so close to each other that the longitudinal evolution of the slag size could not be clearly interpreted. 
Two ancient ironworking sites are located in the reaches selected for this study. The site farthest upstream is situated close to Couvin (Furnace Saint-Roch) and was founded in AD 1737. The other site is situated downstream of Nismes; this blast furnace was founded before AD 1431 (Vanderheyden, 2003).

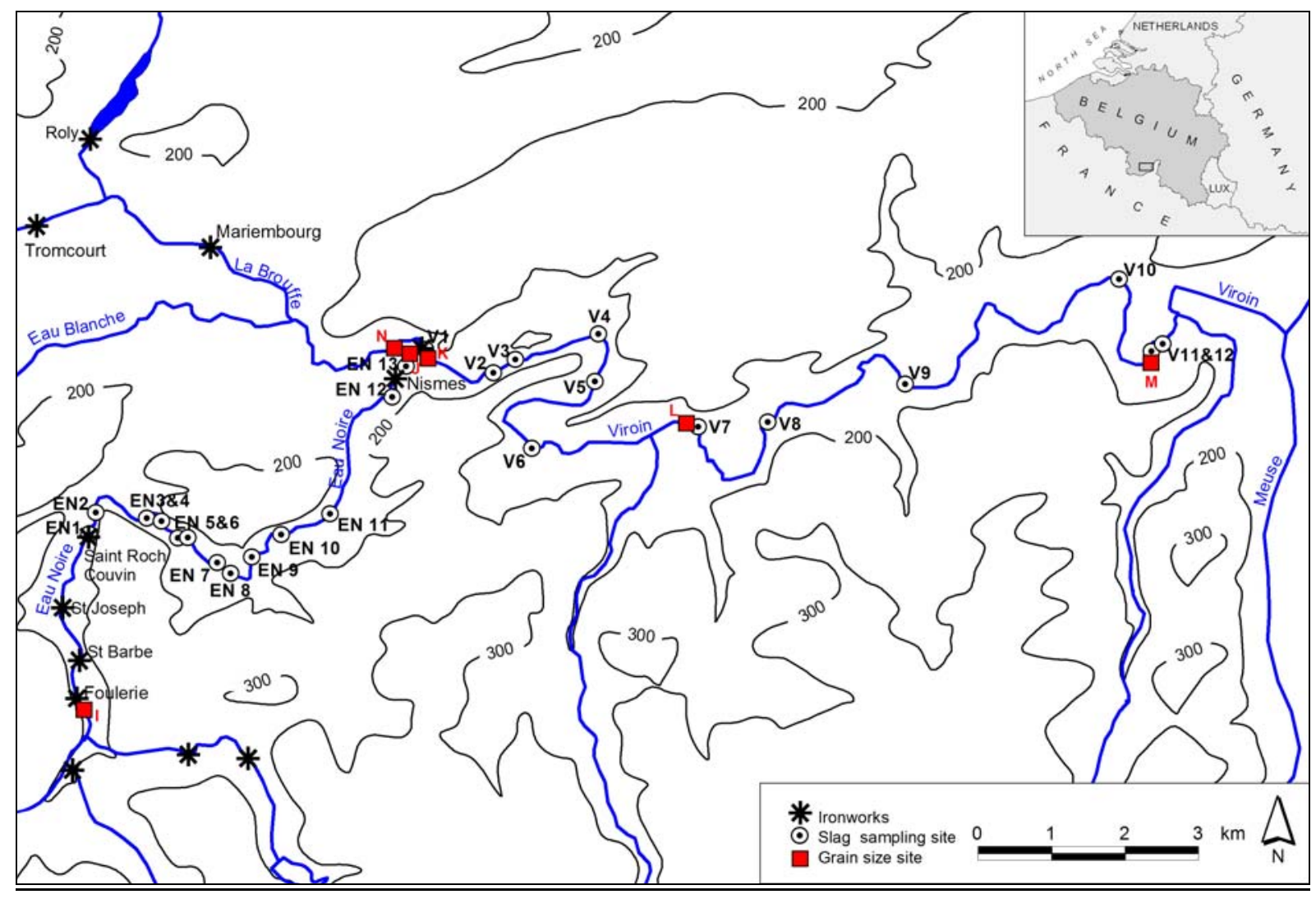

Figure 2: Location map of the Viroin River showing the study reach, the ironworks, the slag sampling sites (sites EN1-V12) and the riffles where grain size have been determined (sites I-Q).

\section{History of the ironworking industry and description of the iron slag}

From the fourteenth century on, ironworks were established along rivers, which allowed them to access water power used to action bellows and forge trip hammers. The finery process, an alternative method of decarburizing pig iron, appeared in the fifteenth century in Belgium. Pig iron was produced in charcoal-fired blast furnaces and refined afterward in forges to oxidize the carbon and the impurities in order to produce malleable wrought iron. This method was widespread all over Europe until the nineteenth century (Leboutte, 1979).

In Wallonia, historical studies and field surveys allowed us to locate more than 300 ancient ironworks along tens of rivers. The ironworks were located in the vicinity of forests and ore deposits. Most of them were situated south of the West-East axis formed by the Sambre and Meuse Rivers (Houbrechts \& Petit, 2004). The inception of the iron industry and the periods of activity were dated (Houbrechts, 2005) in order to calculate the slag propagation velocity.

Slag particles are made up of various by-products of iron smelting. Two types of iron slag are found in large quantities in the bedload of the Ardenne rivers: 
(i) Blast furnace slag (Fig. 3) mainly consists of silicon from the gangue material. These elements are generally green, but can also be blue, beige, or black according to the nature of the ore, its iron content, and the fusion temperature in the furnaces (Corbion, 2003). This type of slag has a glassy appearance because of its high silicon dioxide content and because of its rapid cooling (Serneels, 1993). These slag particles are porous and covered with vacuoles formed by gas bubbles trapped during solidification. This porosity explains why the slag density ranges from 2.2 to $2.5 \mathrm{~g} / \mathrm{cm}^{3}$. Large quantities of slag were produced in blast furnaces. For example, a sixteenth century blast furnace produced about $80 \mathrm{~m}^{3}$ of slag per year (Houbrechts \& Weber, 2007).

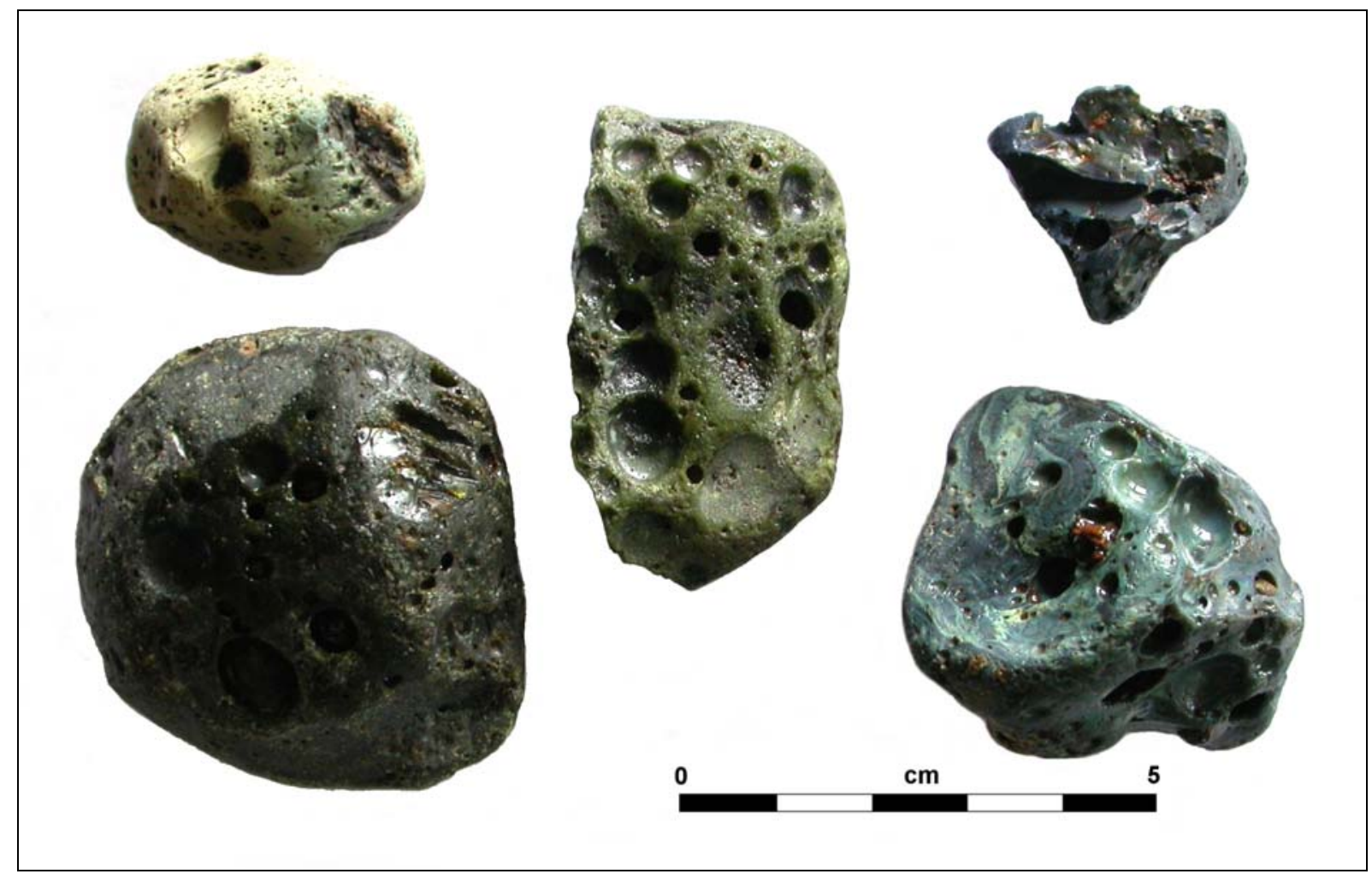

Figure 3: Vitreous slag produced in blast furnace.

Once cooled and hardened, the slag particles were sorted and crushed in order to recuperate metal nodules and any pieces of ore that had not been properly smelted. The slag elements thrown away on disposal sites were therefore relatively small $(<20 \mathrm{~cm})$ and angular. These particles exhibit conchoidal fractures. Meanwhile, the vitreous slag particles found on riverbeds are quite well rounded. Those found in high energy rivers often display fractures resulting from collisions.

(ii) Slag produced in finery forges (Fig. 4) is much denser (density between 3 and $3.8 \mathrm{~g} / \mathrm{cm}^{3}$ ) as it contains up to $50 \%$ iron (Corbion, 2003; Houbrechts \& Weber, 2007). Finery slag could be quite large $(>50 \mathrm{~cm})$, but was generally broken into pieces before disposal. These black slag elements have a slightly rough surface covered with vacuoles. They display traces of oxidation and sometimes streaks of charcoal. This type of slag is more resistant to impact than blast furnace slag, but it is sometimes shattered by internal oxidation (Houbrechts, 2005). 


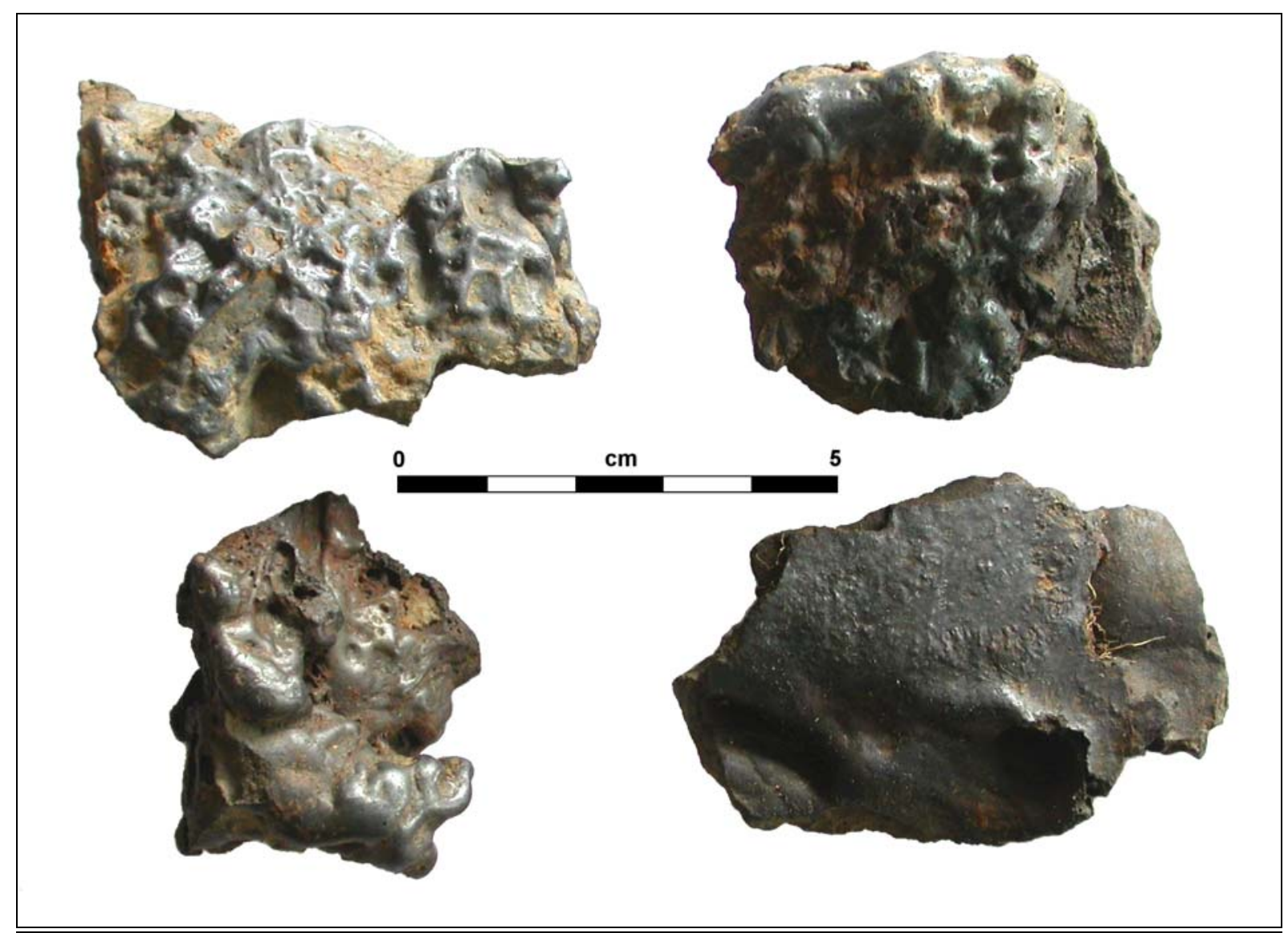

Figure 4: Slag produced in refining forges.

\section{Methods}

Bedload transit can be documented by analyzing the longitudinal dispersion of the largest slag elements from the ironworks where they were produced. Due to their distinctive appearance, slag particles are easily recognizable among the natural pebbles. The largest slag particles present in the surface layer of riffles were collected and measured. Several studies have emphasized that shear stress is lesser on riffles than in pools during floods (Lisle, 1979; Petit, 1987; Thompson et al., 1999; Caamano et al., 2009). In this way, riffles act like filters for bedload dispersion. Consequently, the size of the largest elements observed on riffles gives an idea of the maximal stream competence (Bravard \& Petit, 2000).

Riffles that are partly emerged at low flows were sampled. We collected the largest slag elements on riffles situated directly downstream of ironworks and on tributaries along which ironworks used to be in operation. Intermediary riffles were also sampled in order to better understand slag fining downstream of injection sites. An increase in the size of slag elements as one moves downstream generally indicates that a slag disposal site was present between the two riffles. In such a case, additional sampling sites were selected in order to precisely locate the slag source. Generally, the origin of slag particles produced by different blast furnaces or finery forges established in the same valley cannot be distinguished. As these slag particles were produced using the same techniques and during the same period, their characteristics are very similar.

The number of slag particles collected varies from one site to another - from a few dozen to several hundred - depending on the riffle size, the amount of injected slag, and the distance from the disposal sites.

We tested several different grain size indicators in order to evaluate the longitudinal evolution of the largest slag particles transported by the river. The average $b$-axis diameter of the 10 
largest slag elements $\left(M_{10}\right)$ collected in a riffle proved to be the most efficient indicator. Indeed, the $b$-axis can be measured quickly in the field. In addition, the average size of the 10 largest elements is a good indicator of the maximal size of the sample, which is close to $D_{95}$ of the grain-size distribution. Moreover, a number of studies have repeatedly concluded that the $D_{95}$ parameter for mobilized bedload constitutes the best indicator of flood competence (Komar \& Carling, 1991; Wilcock, 1992; Whitacker \& Potts, 2007).

The average size of the 10 largest slag elements decreases when moving downstream of the injection site. Such downstream fining is characteristic of bedload transport and has been described by several authors (Knighton, 1982; Werritty, 1992; Rice, 1999; Gob et al., 2005). Downstream fining is due to a combination of, firstly, the impact of selective transport on the mobilization of the largest elements and, secondly, the influence of attrition (abrasion, chemical weathering etc.) in reducing the size of particles. The longitudinal decrease of the bed slope can also influence the specific stream power and reduce the competence of rivers. Werritty (1992) studied the longitudinal evolution of the average size of the 10 largest elements for various lithologies in several rivers of the Tatras Mountain range. He differentiated hydrological sorting reaches, located directly downstream of injection sites, from reaches solely undergoing attrition processes. He then applied Eq. (3) to these reaches.

$D_{\text {max }}=D_{0} e^{(-(c+d) x)}$

$D_{0}$ denotes the initial size at distance zero and $D_{\max }$ the maximum particle size at distance $x$. The size reduction coefficient equals - $(c+d)$ with $c$ corresponding to attrition only and $d$, to selective transport only.

Exponent $c$ is obtained by applying Eq. (3) to measurements carried out on the largest elements transported by the river in the plateau reach (downstream of hydrological sorting reaches). This paper uses the expression "plateau reach" to describe reaches with a relatively stable slag size over several kilometers. Indeed, in this reach the size of the largest elements decreases slowly and solely due to attrition processes. Subsequently, by applying this equation to the sorting reaches, $c+d$ can be determined, i.e., the combination of selective transport and attrition. Finally, the $d$-coefficient value is obtained by subtracting the value of $c$ from $c+d$.

This method was applied to the slag evolution curves in order to determine the sorting processes that characterize each river and in order to assess the importance of slag attrition. We must stress that the sampling site located at the boundary between the sorting and plateau reaches was used for calculating both equations. The slag size at the injection sites was not taken into account, as this value is independent of the river's competence.

In the reaches where slag was collected, the grain size on the surface of riffles was determined by sampling and measuring 100 particles at each site, according to the methodology described by Wolman (1954). The riffle grain size percentiles $D_{90}$ and $D_{50}$ were superposed upon the longitudinal trend curves of the average size of the 10 largest slag particles in order to highlight possible hiding or protrusion effects affecting the slag relative to other riverbed components.

As considerable amounts of slag particles were injected into the studied rivers since the inception of the ironmaking industry, slag was dispersed in the form of a sediment wave with a downstream propagation front. Locating the propagation front allows the maximum distance covered by slag elements to be determined. Based on a number of historical studies, the establishment of ironworks may be accurately dated. As the maximum distance covered by slag elements (as well as the length of time that they had been transported by the 
river) is known, the slag propagation velocity can be calculated. This speed can then be transposed to the "natural" components of the bedload. Where ironworks were operating very close to one another, the propagation fronts cannot be distinguished, as slag from various sites was mixed together. However, based on the distance between two sites and the time since the slag was first disposed of in the river, minimal propagation velocity can be assessed.

\section{Results}

For each river studied, a graph illustrating the longitudinal evolution of the average size of the 10 largest slag particles present on the riffles $\left(M_{10}\right)$ was constructed. These graphs highlight the injection sites, followed downstream by sorting reaches. In these reaches, the slag size quickly decreases over a distance ranging from a few hundred meters to a few kilometers, depending on the river. This downstream fining is usually not the outcome of a reduction in river competence but of selective transport. Farther downstream, we systematically observed a stabilization of the slag size. In these reaches, which appear as plateaus on the graphs, the slag size still tends to slowly decrease due to the wearing down and shattering of slag particles by the river processes.

\subsection{Longitudinal evolution of slag size and virtual velocity}

\subsubsection{The Rulles River}

Figure 5 shows the longitudinal evolution of slag size in the Rulles River and its continuation into the Semois River. Our study is based on measurements carried out by Sluse and Petit (1998). Additional sampling was carried out in order to better define the sorting reaches downstream of injection sites and to determine the slag size at the different injections sites. On this graph, two other curves are represented. They correspond to the grain size of riffles $\left(D_{90}\right.$ and $\left.D_{50}\right)$ in order to compare the size of the largest slag particles with the size of the surrounding natural elements.

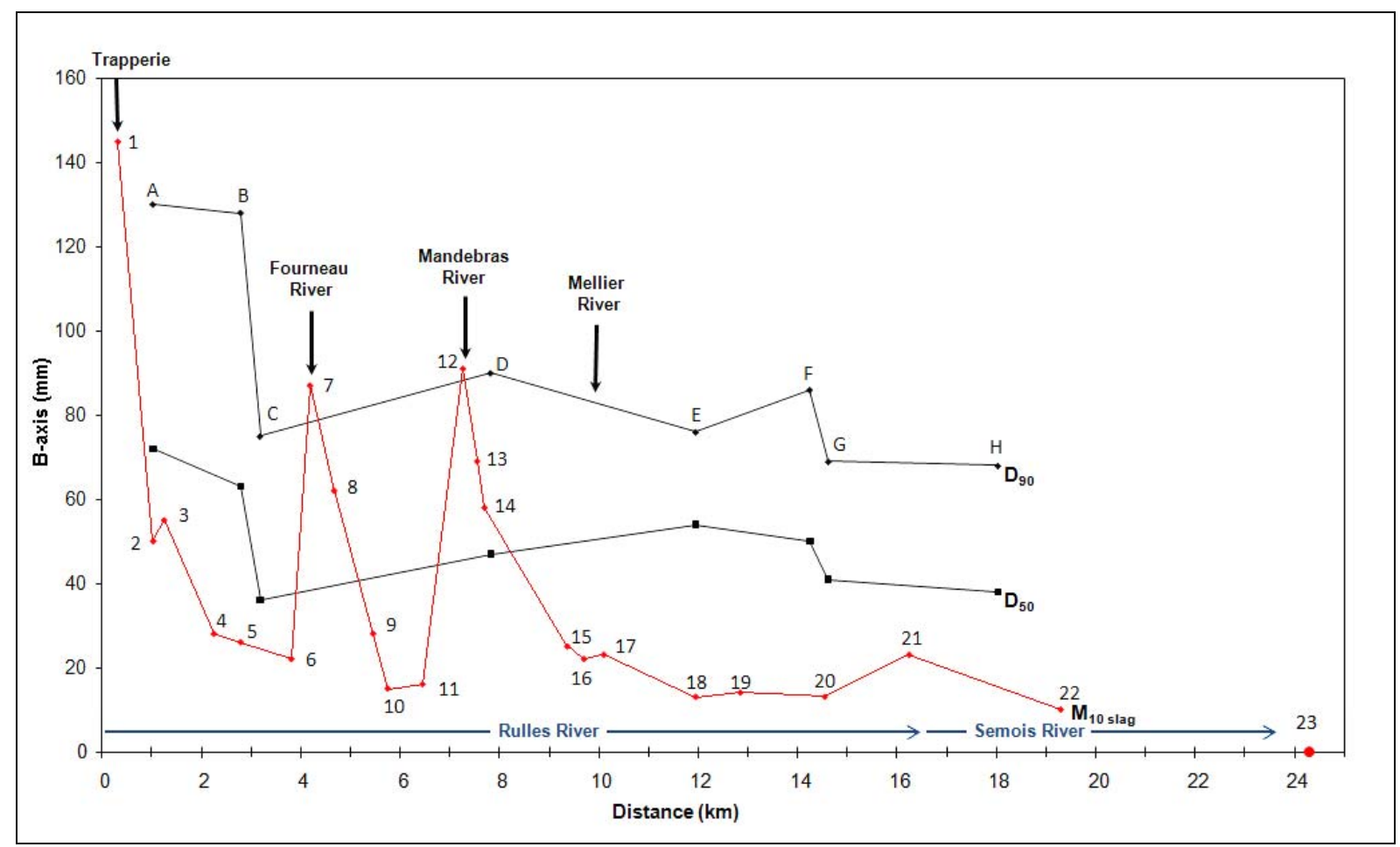

Figure 5: Size slag trend of the 10 largest slag particles along the Rulles River course. Riffles percentiles (D90 and D50) are superposed on this graph. Location of sampling site is presented at figure 1. 
Three slag injection sites stand out clearly on Fig. 5: sites 1, 7 and 12 . The injection at site 1 corresponds to the ironworks at "La Trapperie", where large slag elements $\left(M_{10}=145 \mathrm{~mm}\right)$ cover the riverbed. These slag elements are larger than the $D_{90}$ of the river $(130 \mathrm{~mm})$. They give an indication of the size of the elements that the Rulles River was unable to transport since the ironworks were established in AD 1613. The next injections at sites 7 and 12 correspond to tributaries (Fourneau River and Mandebras River, respectively), where ironworks were established only a few hundred meters upstream of their confluence with the Rulles. These streams supplied quite large slag elements $\left(M_{10}=87\right.$ and $91 \mathrm{~mm}$, respectively) that probably exceeded the competence of the Rulles River. A fourth slag injection site is situated at the confluence with the Mellier (between sites 16 and 17 on the graph), but this injection site does not influence the size of the largest slag elements in the Rulles, because the largest slag size collected in the Mellier River at the confluence is only $16 \mathrm{~mm}$. This relatively small size can be explained by the distance travelled by the slag particles from the ironworks (about $7 \mathrm{~km}$ ) and by the relatively low energy of the stream (cf. Table 1). A slight increase in the size of slag particles is observed at site 21 , but this is not related to a nearby metallurgic site.

Downstream of the injection sites, the average slag size decreases quickly over a distance of about $2 \mathrm{~km}$. This decrease is not due to a decrease in the competence of the river, as the specific stream powers at the bankfull discharge remain constant over the whole reach (cf. Table 1). Rather, this decrease in the average slag size is apparently due to selective transport.

Downstream of the various hydrological sorting reaches, slag size stabilizes systematically. This reflects the effective competence of the Rulles River. A first plateau can be observed between 28 and $22 \mathrm{~mm}$, a second one at around $15 \mathrm{~mm}$, and a third plateau may be observed between 23 and $13 \mathrm{~mm}$, corresponding to the area downstream of the confluence with the Mellier River.

These competence values seem quite low, considering the size of the riverbed material (Fig. 5). On the whole, as one moves downstream, a longitudinal decrease in the size of the particles may be observed: the $D_{90}$ decreases from $130 \mathrm{~mm}$ just downstream of the "La Trapperie" dam (riffle A), to $69 \mathrm{~mm}$ just upstream of the confluence with the Semois River (riffle $G$ ). Only site $C$ deviates from this trend $\left(D_{90}=75 \mathrm{~mm}\right)$. However, this grain size value was obtained in a reach with high lateral mobility (Sluse, 1996), which is likely to have led to the formation of dynamic riffles (where the average size of the riffle material is close to the river competence). Meanwhile, other riffles can be described as resistant riffles, formed by selective entrainment of fine elements. The general longitudinal decrease in the size of elements can be explained by the fact that the Rulles leaves the Paleozoic substratum in the vicinity of "La Trapperie" and then moves on to quite soft Mesozoic rocks. The coarse material is therefore mostly inherited from the upstream part of the catchment and is abraded as it moves downstream. Moreover, the bedload from the Rulles upper catchment is trapped in the dams located upstream of "La Trapperie". Selective transport of the fine elements consequently leads to the development of residual paving in the downstream reach. Upstream of the dams, the $D_{90}$ of the riffle material is much smaller $(62 \mathrm{~mm})$. This type of impact was documented for another Ardenne river (the Warche River) downstream of a hydroelectric dam built in 1931 (Assani \& Petit, 2004).

In addition, 100 pebbles from the Rulles were marked with PIT-tags and injected into the river $2.8 \mathrm{~km}$ downstream of the "La Trapperie" site. They were observed for more than two years. The critical discharge for entrainment in this reach is $8.5 \mathrm{~m}^{3} / \mathrm{s}\left(0.65 \mathrm{Q}_{\mathrm{b}}\right)$ (Levecq et al., 2008). Eight floods with discharges greater than this value occurred during the observation period, including two floods with discharges slightly higher than $\mathrm{Q}_{\mathrm{b}}$. The maximal size of mobilized pebbles is about $75 \mathrm{~mm}$, and this value is close to the maximal competence value estimated using slag at the confluences with the Vieux Fourneau River $\left(M_{10}=87 \mathrm{~mm}\right)$ and the Mandebras River $\left(\mathrm{M}_{10}=91 \mathrm{~mm}\right)$. The marked pebbles were transported over $33 \mathrm{~m}$. The 
largest distance was covered by a $27 \mathrm{~mm}$ long pebble. The average size of the ten pebbles that travelled the greatest distance was also $27 \mathrm{~mm}$. Meanwhile, the average size of the 10 largest slag particles $\left(\mathrm{M}_{10}\right)$ in the same reach was $26 \mathrm{~mm}$. This corresponds to the competence value observed when using marked pebbles.

We should note that the slag size $\left(\mathrm{M}_{10}\right)$ in the plateau reaches is in the same order as the competence estimations by Petit (1987) who used marked pebbles and sediment traps in the upstream reach of the Rulles River.

No slag was found at the farthest study site (site 23). The slag propagation front is thus located between 12 and $17 \mathrm{~km}$ downstream of the closest injection (the Mandebras furnace, founded in $A D$ 1617). The average dispersion velocity of slag in the Rulles River ranges therefore from 3.3 to $4.4 \mathrm{~km} /$ century.

This velocity can be transposed to the whole bedload, under certain conditions. Firstly, the lower density of the blast furnace slag $\left(2.2\right.$ to $\left.2.5 \mathrm{~g} / \mathrm{cm}^{3}\right)$ must be taken into account. Tracing campaigns simultaneously undertaken using painted pebbles and blast furnace slag particles indicate that slag particles move at a slightly higher speed than the natural pebbles (Levecq et al., 2008). Secondly, before transposing this virtual velocity to other gravel-bed rivers, we must take into account that the competence of the Rulles (cf. iron slag and PIT-tags) is inferior to the $D_{50}$ of the material found on the riffles, which can slow down bedload propagation because of the hiding effect.

\subsubsection{The Viroin River}

The graph in Fig. 6 refers to the Eau Noire and Viroin Rivers. Measurements were carried out from the Couvin injection (EN1) down to Vireux-Molhain (France) on the Viroin, i.e., upstream of the confluence with the Meuse River. Twenty-five sites in total were investigated.

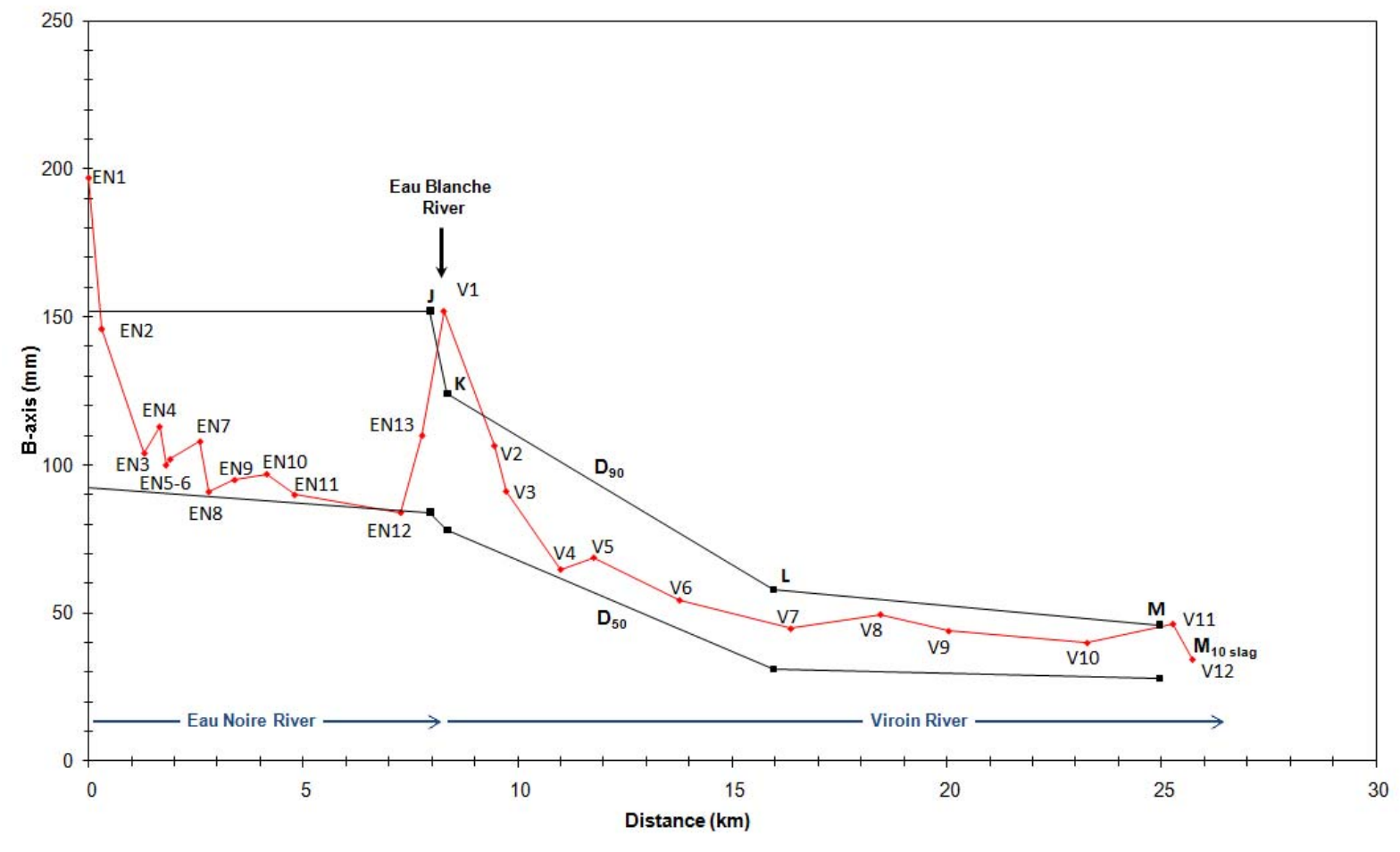

Figure 6: Size slag trend of the 10 largest slag particles along the Eau Noire and the Viroin River courses. Riffles percentiles $\left(D_{90}\right.$ and $\left.D_{50}\right)$ are superposed on this graph. Location of sampling site is presented at figure 1. 
Downstream of the St Roch injection (EN1), the slag size rapidly decreases as one moves downwards to site EN3; this corresponds to the hydrological sorting reach. The slag size increases very slightly in the vicinity of site EN4, and then decreases down to site EN12 $\left(M_{10}\right.$ $=84 \mathrm{~mm}$ ), which corresponds to the plateau reach. Further downstream, the slag size increases close to riffle EN13, and particularly close to riffle V1. This size increase is linked to a slag injection on the Eau Noire River, close to Nismes. Downstream of V1, a new hydrological sorting reach is observed down to $\mathrm{V} 4$ and then a plateau reach between $\mathrm{V} 4$ and V12, i.e., a 15-km-long stretch over which slag size tends to slowly decrease. The plateau lies close to $50 \mathrm{~mm}$. This fining process is described in greater detail in the section dealing with selective transport and slag attrition.

Slag elements from the Eau Blanche River were also measured. These are smaller, as the Eau Blanche has a low specific stream power $\left(31 \mathrm{~W} / \mathrm{m}^{2}\right.$ at the bankfull discharge at the Nismes station) and as the closest ironworks site (Mariembourg) is located on a tributary of the Eau Blanche (la Brouffe) $2.5 \mathrm{~km}$ away from the confluence with the Eau Noire River (cf. Fig. 2). The size of riffle material is also clearly smaller in the Eau Blanche (site $N$ : $D_{90}=70$ $\mathrm{mm} ; \mathrm{D}_{50}=47 \mathrm{~mm}$ ) than in the Eau Noire.

Riffle grain size is quite constant along the Eau Noire River. Meanwhile, a relatively rapid decrease in the size of riffle material occurs between the confluence with the Eau Blanche and V7. Farther downstream, the material size tends to stabilize, while the $D_{90}$ still decreases slightly. This decrease in size over the whole reach is probably not caused by a decreasing competence, as the specific stream power at the bankfull discharge tends to increase slightly downstream of the confluence with the Eau Blanche River. On the other hand, this decrease could be explained by the fact that both the Eau Noire downstream from Couvin and the Viroin River flow through valleys composed of limestone and schist that supply the river with a relatively fine, soft, and soluble load. The Ardenne rocks coming from the upper catchment are thus subject to hydrological sorting in the Viroin River; attrition processes occur in addition. The difference between the $D_{90}$ and the $D_{50}$ decreases between the sites EN1 and V11 (from 68 to $18 \mathrm{~mm}$ ). The $D_{90} / D_{50}$ ratio remains nevertheless proportionally constant (between 1.6 and 1.8).

Outside of the injection sites and the slag sorting reaches, the slag size $\left(M_{10}\right)$ is of the same order as the pebbles measured on the riffles. Furthermore, the longitudinal evolution, on the whole, follows the same trend as the riffle percentiles $D_{90}$ and $D_{50}$. In this river, therefore, the size of riffle material seems to correspond to the river competence. In contrast to the Rulles River, the bedload of the Viroin River is not trapped by dams established in the upstream part of the catchment several centuries ago.

With regard to the slag transport distances, slag particles from site EN1 may not be distinguished from those from site V1. The slag elements found in V12 may originate from site EN1 or even from one of the 15 other ironworking sites located farther upstream. In addition, we did not examine the riffles downstream of V12 as, after this point, the slag from the Viroin River continues its progression into the Meuse River. Considering the distance between V1 and V12 $(17.8 \mathrm{~km})$ and the date that the Nismes furnace was established (ca. $1430 \mathrm{AD}$ ), we calculated that the slag propagation speed in the Viroin is at least 3.1 $\mathrm{km} /$ century.

\subsubsection{Comparison with other rivers}

Using the same methodology, the propagation front of slag injected in the Ourthe River from ca. AD 1500 was located and used to estimate the dispersion velocity of the bedload. As the slag propagation front is located between 9.7 and $12.7 \mathrm{~km}$ from the nearest injection site, the 
slag dispersion velocity is evaluated at between 1.9 and $2.5 \mathrm{~km} /$ century (Houbrechts \& Petit, 2003).

For the other rivers investigated, the distances between neighboring injection sites are so short that locating slag propagation fronts for every single site is impossible. The results obtained therefore correspond to minimal values for bedload transit and are always inferior to the values obtained for the Rulles, Ourthe, or Viroin Rivers.

These results call for further discussion. Duchesne and Pissart (1985) proposed values for the velocity of bedload movement in their study on petrographic variations in the sediments of the Ourthe River. They observed the reduction in size and disappearance of limestone pebbles $250 \mathrm{~mm}$ in diameter over a 5-km-long stretch of the river. Using average dissolution rates $(28 \mathrm{~mm} /$ century) measured on ancient constructions (bridges, weirs, etc.), they estimated bedload movement to be about $0.5 \mathrm{~km} /$ century in the lower Ourthe River. However, using the same observations, but taking the river competence into account and reconsidering the dissolution rate and the impact of abrasion, we calculated that bedload movement could reach up to $1.3 \mathrm{~km} /$ century (Houbrechts, 2000), i.e., a value quite close to the velocity deduced from the slag-based study (Table 2).

Table 2 : Overview of speeds of bedload progression for rivers of the Ardenne and of other regions.

\begin{tabular}{|c|c|c|c|}
\hline Rivers & $\begin{array}{l}\text { Speed of bedload } \\
\text { progression } \\
\text { (km/century) }\end{array}$ & Methods & Reference \\
\hline \multicolumn{4}{|l|}{ Ardenne Massif } \\
\hline Rulles & $3.3-4.4$ & Slag & Sluse and Petit, 1998 \\
\hline Viroin & $>3.1$ & Slag & Vanderheyden, 2003 \\
\hline Ourthe & $1.9-2.5$ & Slag & Houbrechts and Petit, 2003 \\
\hline Ourthe & 0.5 & Sedimentological analyses & Duchesne and Pissart, 1985 \\
\hline Ourthe & $>1.3$ & Sedimentological analyses & Houbrechts, 2000 \\
\hline \multicolumn{4}{|l|}{ Other regions } \\
\hline Isère (Alps - France) & 10 & $\begin{array}{l}\text { Progression of fluvial } \\
\text { metamorphose on old maps }\end{array}$ & Salvador, 1991 \\
\hline $\begin{array}{l}\text { Hérault (Massif } \\
\text { Central - France) }\end{array}$ & 20 & Sedimentological analyses & Tricart and Vogt, 1967 \\
\hline $\begin{array}{l}\text { Borne river (Southern } \\
\text { Prealps - France) }\end{array}$ & 8 & Dendrochronology & Thevenet et al., 2003 \\
\hline $\begin{array}{l}\text { Several rivers of the } \\
\text { Southern Prealps }\end{array}$ & $30-50$ & Dendrochronology & Liébault et al., 2005 \\
\hline
\end{tabular}

The values obtained from the Ardenne rivers can be compared to those observed in other geomorphological regions (Table 2). For example, Tricart and Vogt (1967), in their study of modifications to the petrographical spectrum of the bed material following the construction of a dam on the Herault River, found that the entire bedload was mobilized at a velocity of about $20 \mathrm{~km} /$ century. This value is very high but was obtained on a river characterized by 
steep slopes and canyon reaches where flow velocity is high and pebble transport regularly occurs.

The development of braided channels in the Isère River in response to climatic cooling during the Little Ice Age provides important indications about the speed of the sediment wave propagation front. Salvador (1991) based his observations on the analysis of old cartographical documents and came to the conclusion that this speed was $10 \mathrm{~km} /$ century on the Isère River downstream of Grenoble. We should note that this value corresponds to a period of particularly intense and frequent floods and that this factor is likely to have influenced the river competence and increased the velocity of bedload dispersion. Moreover, in the studied reach, the riverbed material had been sorted and the size of the particles was relatively homogeneous. This indicates that the entire load would probably have been mobilized during floods (J.-P.Bravard, University of Lyon 2, personal communication, 2010).

Bedload propagation velocities obtained by Thevenet et al. (2003) and Liébault et al. (2005) on streams in the Drôme catchment (southern French Prealps) are also clearly higher than those of the Ardenne rivers, but these values were obtained for streams with steeper slopes. These authors analyzed the propagation of river incision using tree-ring dating of vegetation installed on the alluvial banks stabilized by riverbed incision. A first incision phase began in the late nineteenth century in response to a decrease of sediment input. This was due to a reduction in sediment supply resulting from the end of the Little Ice Age, to the reforestation of mountain slopes, and to the modification of streambeds. Incision propagated downstream at a speed of $8 \mathrm{~km} /$ century on the Borne River between 1876 and 1914 (Thevenet et al., 2003). A second incision phase occurred in the twentieth century, caused by the sediment supply decrease following spontaneous reforestation of abandoned agricultural lands (Liébault \& Piégay, 2001). The incision propagation velocity estimated for the period ca. 1940-1980 in seven streams is much higher: between 30 and $50 \mathrm{~km} /$ century (Liébault et al., 2005). However, we should note that the material transported by these streams mainly consists of marls and limestones, both of which are very sensitive to weathering agents and dissolution. As a result, the particles are quickly worn down and the bedload can be mobilized more frequently.

\subsection{Selective transport and slag attrition}

Slag fining downstream of injection sites was studied using the methodology described by Werritty (1992). The curves were divided into two types of reaches: first, the hydrological sorting reaches where slag size decreases quickly; and secondly, the plateau reaches where slag size decreases slowly in relation to attrition processes. All reaches are defined by Eq. (3). These equation exponents allow the reduction in the size of the elements linked to attrition processes to be quantified and hydrological sorting to be defined.

Figure 7 presents observations obtained from the Rulles, the Eau Noire, and the Viroin Rivers. As the Rulles River has a quite constant specific stream power $\left(Q_{b}\right.$ between 27 and $30 \mathrm{~W} / \mathrm{m}^{2}$ ), observations made downstream of the three injections were grouped together for this river, thus increasing the number of measurement points in both reaches on the graph. For each point, the distance to the closest injection site is presented. The values at the injection sites are not considered for this analysis because the size of slag at the injection sites is independent of the characteristics of the rivers. In addition, the points situated at the junction between the sorting reach and the plateau reach are used for calculating the equations of the two reaches. 


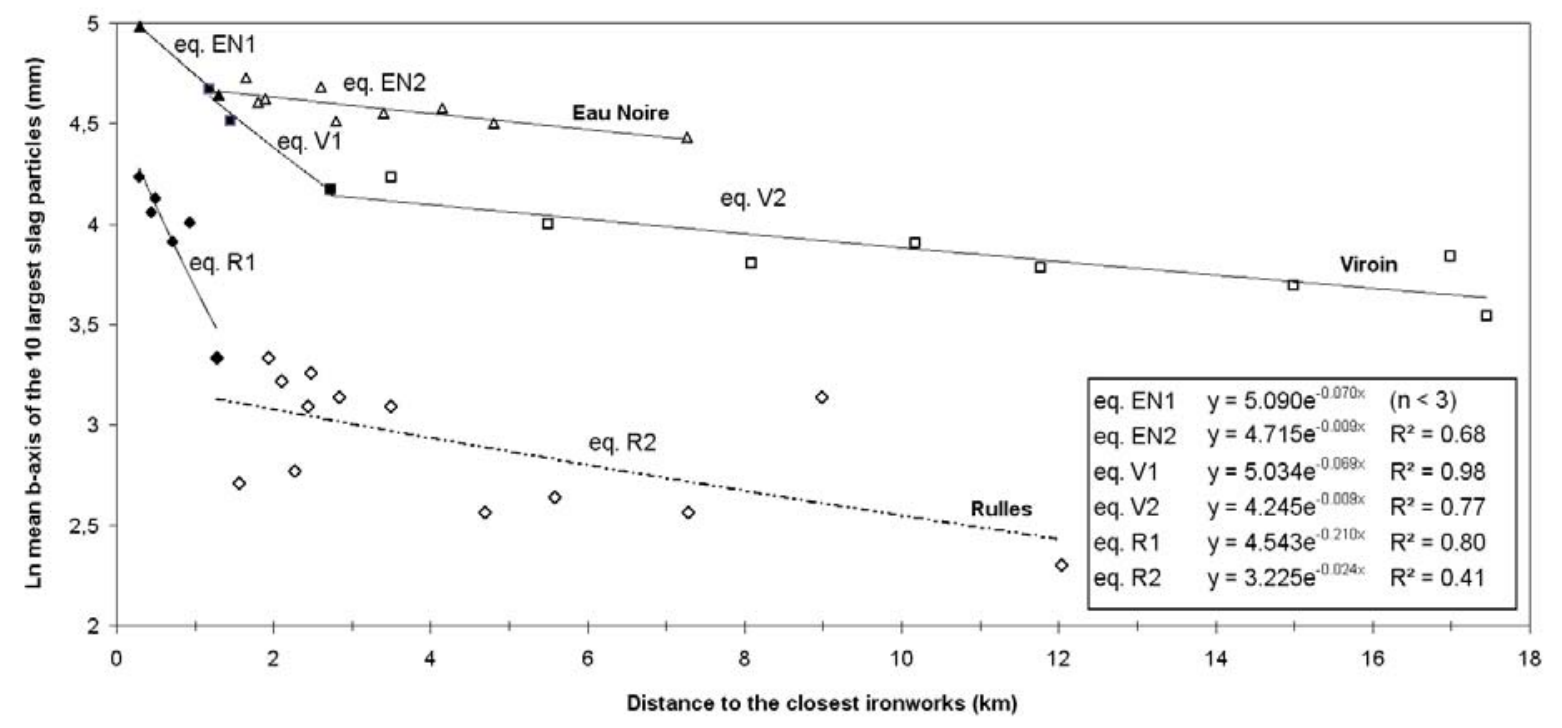

Figure 7: Downstream fining of slag in The Rulles River, the Eau Noire River and the Viroin River, according to the distance to the closest ironworks.

On the basis of these equations, the values of exponents $-c,-(c+d)$ and $-d$ were determined; Table 3 presents the results. Although the sorting reach on the Eau Noire encompasses only two observation points, it is still presented here as its equation exponent seems similar to that of the Viroin River.

Table 3 : Overview of exponents values for the attrition and the selective transport.

\begin{tabular}{lccc}
\hline & $\begin{array}{c}\text { Attrition } \\
\text { only }\end{array}$ & $\begin{array}{c}\text { Attrition and } \\
\text { selective } \\
\text { transport }\end{array}$ & $\begin{array}{c}\text { Selective } \\
\text { transport only }\end{array}$ \\
Eau Noire & $-\mathrm{c}$ & $-(\mathrm{c}+\mathrm{d})$ & $-\mathrm{d}$ \\
Viroin & -0.009 & $-0.070^{*}$ & $-0.061^{*}$ \\
Rulles & -0.009 & -0.069 & -0.060 \\
\hline${ }^{*} \mathrm{n}=2$ & -0.024 & -0.210 & -0.186 \\
\hline
\end{tabular}

The coefficients of determination calculated for these equations are relatively good, except for the equation characterizing slag attrition in the Rulles River. This equation is influenced by the increase in slag size at sampling site 21 (cf. fig 5). Without this point, the attrition coefficient would be greater $(-0.032)$ and the $R^{2}$ value would reach up to 0.64 .

The equation exponent characterizing slag attrition $-c$ is the same for the Viroin and the Eau Noire (-0.009). However, in the Rulles, slag is subject to greater wearing $(-0.024)$. This difference could be linked to the different slag types: most of the measurements in the Rulles were carried out on vitreous slag produced by blast furnaces, while finery slag was also present in the two other rivers. Impact strength testing in a laboratory indicates that blast furnace slag particles are more shock-sensitive than finery slag (Houbrechts, 2005). 
In comparison, Werrity (1992) obtained attrition values of $-0.003,-0.012$, and -0.032 , respectively, downstream of quartzite, granite, and limestone injection sites. The values measured in this study (between -0.009 and -0.024) therefore fall between granite and limestone values. However, as this study was carried out on relatively moderate energy rivers $\left(\omega_{\mathrm{Qb}}=25\right.$ to $\left.65 \mathrm{~W} / \mathrm{m}^{2}\right)$, the impacts between bedload elements are likely to have been less violent than in the rivers studied by Werritty. Moreover, attrition by sandblasting is probably also more important in Werritty's study sites as the granite present in those catchments releases sand when subject to arenaceous weathering. The attrition of the largest elements of the bed material of the Rulles River can be investigated by analyzing the $D_{90}$ values downstream of "La Trapperie", as most of the coarse load is inherited from the upper catchment. The exponent of size reduction for the Rulles bed material is -0.006 , i.e., four times less than that of slag in the same river. The same methodology can be applied to the Viroin River in which coarse riverbed elements are mostly Ardenne rocks originating from the upper catchment. However, the curve for the Viroin seems to indicate a sorting reach between riffles $K$ and $L$, followed by a reach with attrition only (riffle $L$ to $M$ ). For this last reach, the size reduction exponent is -0.007 , i.e., a value quite similar to the one obtained for the Rulles bed material and for the Viroin slag elements.

Selective transport of slag varies downstream of the injection sites (Fig. 7). The sorting distance of the Viroin, which has a lower exponent value $(-0.060)$, is larger than that of the Rulles. This difference may be explained by the fact that slag injection in the Viroin dates back longer than in the Rulles. Indeed, the length of the sorting reach increases over time because of the increasing number of floods that can mobilize the largest elements. For example, the sorting reach for the PIT-tags injected in the Rulles advanced over a distance of only $14 \mathrm{~m}$ over a two-year observation period (with a coefficient of -14.1 for selective transport only), while the sorting reach for the slag disposed in the river in the early seventeenth century is about $1.3 \mathrm{~km}$ long (with $-d=-0.186$ ).

These differences can also be linked to an excess of unit stream power available for bedload transport. Gob et al. (2010) show that rivers with the lowest excesses of stream power display the shortest sorting reaches and, therefore, develop a better downstream fining. This hypothesis could explain the sorting differences between the Viroin and the Rulles: the selective transport coefficient is larger for the Viroin; the Viroin has greater competence (see the slag size in the plateau reach) and larger specific stream powers at the bankfull discharge, which indirectly imply a greater excess of power.

\subsection{Comparison between slag size $\left(M_{10}\right)$ in the plateau reaches and specific stream powers at the bankfull discharge}

A relationship between the average size of the 10 largest slag particles $\left(M_{10}\right)$ in plateau reaches and specific stream powers at the bankfull discharge $\left(\omega_{\mathrm{Qb}}\right)$ has already been proposed on the basis of observations of several rivers from the northern and southern Ardenne region (Houbrechts \& Petit, 2003). The new observations highlight the impact of the surrounding material size on the mobilization of slag particles.

When plotting the slag $\mathrm{M}_{10}$ average values for plateau reaches against specific stream power values at the bankfull discharge for the same reaches, the dots are quite dispersed. The coefficient of determination calculated for the whole data set is low $\left(R^{2}=0.31\right)$. According to Ferguson (2005), the critical specific stream power for mobilizing elements of a given size also depends on the surrounding material size (hiding or protrusion effects) and, to a lesser extent, on the slope. In order to verify whether the slag size relative to the bed material can explain the dispersion of the dots, the ratio between the $M_{10}$ in the plateau reaches and the $D_{50}$ of the riffles in the same reaches was calculated. The reaches were then grouped into three categories: 
(i) $M_{10}$ values clearly lower than $D_{50}\left(M_{10} / D_{50}<0.8\right)$,

(ii) $M_{10}$ values roughly similar to $D_{50}\left(M_{10} / D_{50}\right.$ between 0.8 and 1.2$)$, and

(iii) $M_{10}$ values clearly higher than $D_{50}\left(M_{10} / D_{50}>1.2\right)$.

Two regressions were established: one for the category with slag particles hidden by other riverbed elements $\left(M_{10} / D_{50}<0.8\right)$ and one for the category with protruding slag elements $\left(\mathrm{M}_{10} / \mathrm{D}_{50}>1.2\right)$ (Fig. 8).

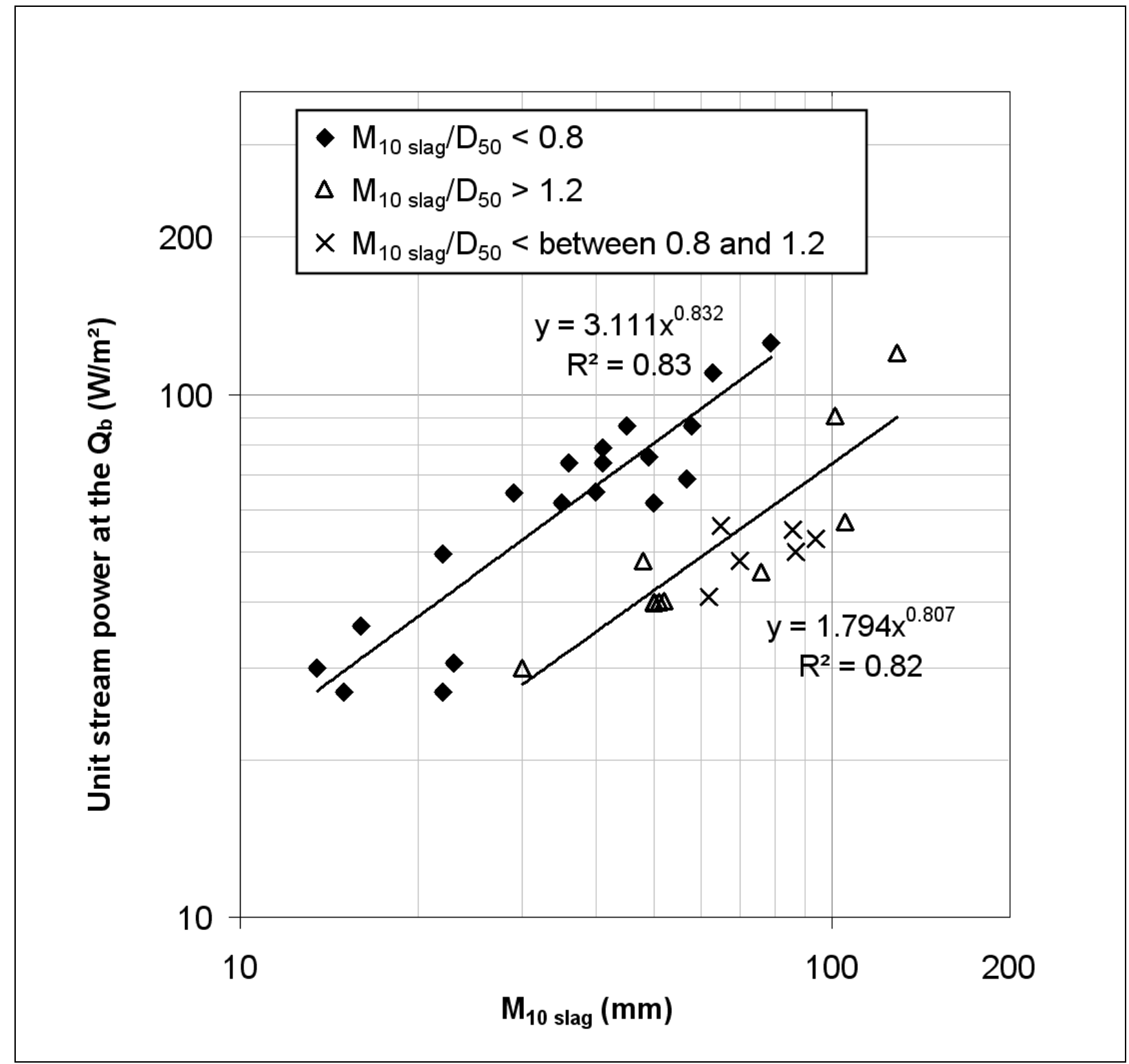

Figure 8: The average size of the ten largest slag particle $\left(M_{10}\right)$ in plateau sectors of the studied rivers is plotted against specific stream powers at the bankfull discharge. The data set is split between various categories on the basis of the $M_{10} / D_{50}$ value. Linear regressions are established for two of these categories. Refer to the text for further details.

Differentiating the data on the basis of $M_{10}$ values led to the definition of two distinct and reliable relations $\left(R^{2}=0.83\right.$ and 0.82$)$ between the $\mathrm{M}_{10}$ and the unit stream power at the bankfull discharge $\left(\omega_{\mathrm{Qb}}\right)$. The data set used for calculating the coefficient of determination for protruding slag is not as large as that used for hidden slag. The protruding slag dots are 
nevertheless aligned with dots from the $0.8<M_{10} / D_{50}<1.2$ category. For slag particles of equal size, those pertaining to the $M_{10} / D_{50}<0.8$ category are mobilized by much larger specific stream powers. This observation, based on field measurements, supports experimental results obtained in flumes (Fenton \& Abott, 1977; Andrews, 1983; Petit, 1994).

On the basis of the two proposed equations, a quite reliable estimation of the specific stream power at the bankfull discharge $\left(\omega_{\mathrm{Qb}}\right)$ can be proposed for gravel-bed rivers with a single channel. This estimation is based on the measurement of the average size of the 10 largest slag particles $\left(M_{10}\right)$ in plateau reaches and on the calculation of the $M_{10} / D_{50}$ ratio.

\section{Conclusion}

Iron slag is a reliable tracer for studying bedload propagation, as for centuries it has been subject to the same conditions as the natural bedload elements. Slag elements found in the vicinity of the long-closed ironworks provide indications about the maximal competence of the river. Hydrological sorting reaches located downstream of the ironworks allow the dispersion velocity of the largest slag elements to be analyzed. Plateau reaches, where the largest slag size remains roughly constant regardless of the distance travelled, provide information about the river's effective competence. By analyzing the average size of the 10 largest slag particles in plateau reaches in relation to the specific stream power at the bankfull discharge, we observed that the size of riverbed material influences the river competence (through hiding and protrusion effects). When injection sites are located far enough from one another, the slag propagation front can be located. In this way, the virtual velocity of bedload movement can be estimated. For two gravel-bed rivers of the Ardenne massif, we calculated that this velocity is between 2 and $4 \mathrm{~km} /$ century.

\section{Acknowledgements}

The authors are thankful to Professor J.-P. Bravard (University of Lyon 2, France) for his comments and suggestions on this paper. They would like also to thank the two anonymous reviewers for their constructive remarks. Hydrological data were kindly made available to us by the DCENN (Direction des Cours d'eau Non Navigables de la Région Wallonne) and the MET-SETHY (Service Hydrologique du Ministère de l'Equipement et des Transports). We are grateful to Ang. Prick, N. Shields, and S. Mills for translating this paper and to J. Laval, C. Delforge, E. Tallier, and C. Nihoul for their help with field work. Finally, we thank the FRIA of the French Community of Belgium for financing the doctoral grant during which this research was carried out. 


\section{References}

Allard, C., 1979. L'industrie du fer dans les pays de Couvin et de Chimay: 1730 - 1830. Essai d'Histoire économique et sociale. Société d'Histoire Régionale de Rance 9, 206 pp.

Andrews, E.D., 1983. Entrainment of gravel naturally sorted riverbed material. Geological Society of American Bulletin 94, 1225-1231.

Assani, A.A., Petit, F. 2004. Impact of hydroelectric power releases on the morphology and the sedimentology of the bed of the Warche River (Belgium). Earth Surface Processes and Landforms 29 (2), 133-143.

Billi, P., 1988. A note on cluster bedform behaviour in a gravel-bed river. Catena, 15: 473481.

Bourguignon, M., 1926-1927. Les usines du Bassin de la Rulles. Annales de l'Institut archéologique du Luxembourg 57-58, 1-84 and 41-172.

Bravard, J.-P., Petit, F., 2000. Les Cours D'eau : Dynamique du Système Fluvial. A. Colin, Paris, $222 \mathrm{pp}$.

Busskamp, R., Hasholt, B., 1996. Coarse bed load transport in a glacial valley, Sermilik, south east Greenland. Zeitschrift für Geomorphologie 40 (3), 349-358.

Caamano, D., Goodwin, P., Buffington, J.M., Liou, J.C.P., Daley-Laursen, S., 2009. Unifying criterion for the velocity reversal hypothesis in gravel-bed rivers. Journal of Hydraulic Engineering 135(1), 66-70. doi: 10.1061/(ASCE)0733-9429(2009)135:1(66).

Corbion, J., 2003. Le Savoir...Fer, Glossaire du Haut-Fourneau. Edited by the Association Le savoir...fer, $4^{\text {th }}$ edition, Florange, France, $3441 \mathrm{pp}$ (4 vol.).

de Moreau de Gerbehaye, C., 1987-1988. De la "mine" à la "barre". La sidérurgie en Gaume avant la révolution industrielle. Le Pays gaumais 48-49, 145-167.

Duchesne, F., Pissart, A., 1985. Valeur stratigraphique des comptages des cailloux de différentes lithologies. Bulletin de la Société Géographique de Liège 21, 13-23.

Ergenzinger, P., Schmidt, K.D., Busskamp, R., 1989. The pebble transmitter system (PETS): First results of a technique for studying coarse material erosion, transport and deposition. Zeitschrift für Geomorphologie 33, 503-508.

Evrard, R., 1956. Forges Anciennes. Éditions Solédi, Liège, Belgium, 227 pp.

Feltz, C., Incourt, A.-F., 1995. Itinéraire de la sidérurgie du XVI" au XX" siècle en Sud Ardenne et en Gaume. Société royale belge de Géographie 26, 56 pp.

Fenton, J.D., Abbott, J.E., 1977. Initial movement of grains on a stream bed: the effect of relative protrusion. Proceedings of the Royal Society of London 352 (A), 523-537.

Ferguson, R.I., 2005. Estimating critical stream power for bedload transport calculations in gravel-bed rivers. Geomorphology 70 (1-2), 33-41.

Ferguson, R.I., Bloomer, D.J., Hoey, T.B., Werritty, A., 2002. Mobility of river tracer pebbles over different timescales. Water Resources Research 38 (5), 10.1029/2001WR000254. 
Gillard, A., 1971. L'industrie du fer dans les localités du Comté de Namur et de l'EntreSambre-et-Meuse de 1345 à 1600. Histoire Pro Civitate, 29. Crédit communal de Belgique, Bruxelles, 263 pp.

Gintz, D., Hassan, M.A., Schmidt, K.H., 1996. Frequency and magnitude of bedload transport in a mountain river. Earth Surface Processes and Landforms 21, 433-455.

Gob, F., Bravard, J.-P., Jacob, N., Petit, F., 2005. Determining the competence of mountainous Mediterranean streams using lichenometric techniques. In: Batalla, R.J., Garcia, C. (Eds.) Geomorphological Processes and Human Impacts in River Basins. Proceedings of the International Conference held at Solsona, Catalonia, Spain, May 2004. IAHS Red Book, 299, Wallingford, UK, 161-170.

Gob, F., Bravard, J.-P., Petit, F., 2010. The influence of sediment size, relative grain size and channel slope on initiation of sediment motion in boulder bed rivers: a lichenometric study. Earth Surface Processes and Landforms 35 (13), 1535-1547. doi: 10.1002/esp.1994.

Hassan, M.A., 1990. Scour, fill, and burial depth of coarse material in gravel bed streams. Earth Surface Processes and Landforms 15, 341-356.

Houbrechts, G., 2000. Utilisation des macroscories comme indicateur du transport de la charge de fond des rivières de la "Terre de Durbuy". Mémoire de Licence en Sciences Géographiques, Université de Liège, Belgium, 137 pp.

Houbrechts, G., 2005. Utilisation des macroscories et des microscories en dynamique fluviale: application aux rivières du massif ardennais. Thèse de doctorat, Université de Liège, Belgium, 328 pp.

Houbrechts, G., Petit, F., 2003. Utilisation des scories métallurgiques en dynamique fluviale : détermination de la compétence effective des rivières et estimation des vitesses de progression de leur charge de fond. Géomorphologie : relief, processus, environnement 1, 3-12.

Houbrechts, G., Petit, F., 2004. Étude de la dynamique fluviale des rivières ardennaises grâce aux scories métallurgiques. De la Meuse à l'Ardenne 36, 57-68.

Houbrechts, G., Weber, J.-P., 2007. La sidérurgie proto-industrielle dans le bassin de la Lienne. De la Meuse à l'Ardenne 39, 34-63.

Juvigné, E., 1979. L'encaissement des rivières ardennaises depuis le début de la dernière glaciation. Zeitschrift für Geomorphologie 23, 291-300.

Knighton, A.D., 1982. Longitudinal changes in the size and shape of stream bed material : Evidence of variable transport conditions. Catena 9, 25-34.

Knighton, A.D., 1999. Downstream variation in stream power. Geomorphology 29, 293-306.

Komar, P.D., Carling, P.A.,1991. Grain sorting in gravel-bed streams and the choice of particle sizes for flow competence evaluations. Sedimentology 38, 489-502.

Kondolf, G.M., Matthews, W.V.G., 1986. Transport of tracer gravels on a coastal California river, Journal of Hydrology, 85: 265-280.

Kondolf, G.M., Lisle, T.E., Wolman, G.M., 2003. Bed Sediment Measurement. In Kondolf, G.M. and Piégay, H., Editors. Tools in Fluvial Geomorphology, Wiley, Chichester, pp. 347395. doi:10.1002/0470868333. 
Lamarre, H., Roy, A.G., MacVicar, B., 2005. Using PIT tags to investigate sediment transport in gravel-bed rivers. Journal of Sedimentary Research, 75: 736-741.

Leboutte, R., 1979. La grosse forge wallonne (du XVe au XVIIle siècle). Editions du Musée de la Vie wallonne, Liège, Belgium, $53 \mathrm{p}$.

Levecq, Y., Houbrechts, G., Van Campenhout, J., Hallot, E., Mols, J., Peeters, A., Petit F., 2008. Caractérisation et quantification du transport des sédiments en rivières (matières en suspension et charge de fond) en relation avec une différenciation régionale. Convention 05/43364 DCENN, Second part: Charge de fond: $172 \mathrm{pp}$.

Leopold, L.B., Emmett, W.W., Myrick, RM., 1966. Channel and hillslope processes in a semiarid area, New Mexico. Geological Survey, Professional Paper 352 G, 193-253.

Liébault, F., Piégay, H., 2001. Assessment of channel changes due to long-term bedload supply decrease, Roubion River, France. Geomorphology 36, 167-186.

Liébault F., Gomez B., Page M., Marden M., Peacock D., Richard D., Trotter C. M., 2005. Land-use change, sediment production and channel response in upland regions. River Research and Applications 21, 739-756.

Lisle, T.E., 1979. A sorting mechanism for a riffle-pool sequence. Geological Society of America Bulletin 90, 1142-1157.

MacNamara, J., Borden, C., 2004. Observations on the movement of coarse gravel using implanted motion-sensing radio transmitters. Hydrological Processes 18, 1871-1884.

Petit, F., 1987. The relationship between shear stress and the shaping of the bed of a pebble-loaded river (La Rulles-Ardenne). Catena 14 (5), 453-468.

Petit F., 1994. Dimensionless critical shear stress evaluation from flume experiments using different gravel beds. Earth Surface Processes and Landforms 19, 565-576.

Petit, F., Pauquet, A., 1997. Bankfull discharge recurrence interval in gravelbed rivers. Earth Surface Processes and Landforms 22, 685-693.

Petit, F., Gob, F., Houbrechts, G., Assani, A.A., 2005a. Critical specific stream power in gravel-bed rivers. Geomorphology, 69, 92-101.

Petit, F., Hallot, E., Houbrechts, G., Mols, J., 2005b. Evaluation des puissances spécifiques de rivières de moyenne et de haute Belgique. Bulletin de la Société Géographique de Liège 46, 37-50.

Pirotte, F., 1967. L'industrie métallurgique de la Terre de Durbuy de 1480 à 1625. Ses rapports avec la métallurgie liégeoise. Bulletin de l'Institut archéologique liégeois 79, 145-210.

Rice, S., 1999. The nature and controls on downstream fining within sedimentary links. Journal of Sedimentary Research, 69 (1): 32-39.

Rollet, A.J., MacVicar, B., Piégay, H., Roy, A., 2008. L'utilisation de transpondeurs passifs l'estimation du transport sédimentaire: premiers retours d'expérience. La Houille Blanche 4, 110-116.

Salvador, P.G., 1991. Le Thème de la métamorphose fluviale dans les plaines alluviales du Rhône et de l'Isère - Bassin de Malville et Ombillic de Moirans (Isère, France). Thèse de Géographie et Aménagement, Université Lyon III, 498 pp. 
Schick, A.P., Hassan, M.A., Lekach, J., 1987. A vertical exchange model for coarse bedload movement: Numerical considerations, in Geomorphological models - Theoretical and empirical aspects, Catena Supplement 10, 3-83.

Schmidt, K.H., Ergenzinger, P., 1992. Bedload entrainment, travel lengths, step lengths, rest periods-studied with passive (irons, magnetic) and active (radio) tracer techniques. Earth Surface Processes and Landforms 17, 147-165.

Serneels, V., 1993. Archéométrie des scories de fer. Recherches sur la sidérurgie ancienne en Suisse occidentale, Cahiers d'Archéologie romande 61, 240 p.

Sluse, P., 1996. Évolutions de la Rulles, de la Semois et de la Mellier au cours des cinq derniers siècles grâce aux résidus métallurgiques de l'Industrie du fer et par l'étude des cartes anciennes. Mémoire de licence en Sciences géographiques, Université de Liège, 206 p.

Sluse, P., Petit, F., 1998. Evaluation de la vitesse de déplacement de la charge de fond caillouteuse dans le lit des rivières ardennaises au cours des trois derniers siècles, à partir de l'étude des scories métallurgiques. Géographie physique et Quaternaire 52, 373-380.

Thevenet, G., Astrade, L., Bravard, J.-P., 2003. La métamorphose des lits torrentiels à la fin du 19 e siècle. Un effet du changement climatique ou du reboisement. Cahiers de Géographie 1, 115-122.

Thompson, D.M., Wohl, E.E., Jarrett, R.D., 1999. Velocity reversals and sediment sorting in pools and riffles controlled by channel constrictions. Geomorphology 27 (3-4), 229-241. doi:10.1016/S0169-555X(98)00082-8.

Tricart, J., Vogt, H., 1967. Quelques aspects du transport des alluvions grossières et du façonnement dans les lits fluviaux. Geografiska Annaler 49A, 351-366.

Vandenberghe, J., 1995. Timescales, climate and river development. Quaternary Science Reviews 14, 631-638.

Vandenberghe, J., 2008. The fluvial cycle at cold-warm-cold transitions in lowland regions: A refinement of theory. Geomorphology 98, 275-284.

Vanderheyden, V., 2003. Dynamique fluviale du Viroin. Contribution à la détermination des zones inondables du bassin, évolution des inondations, morphométrie et transport de la charge de fond. Mémoire de Licence en Sciences Géographiques, University of Liège, Belgium, $114 \mathrm{p}$.

Werritty, A., 1992. Downstream fining in a gravel-bed river in southern Poland : lithologic controls and the role of abrasion. In: Hey, R.D., Thorne, C.R. and Tacconi, P., Editors. Dynamics of Gravel-Bed Rivers, Wiley, Chichester, pp. 333-350.

Whitacker, A., Potts, D.F., 2007. Coarse bed load transport in an alluvial gravel bed stream, Dupuyer Creek, Montana. Earth Surface Processes and Landforms, 32: 1984-2004.

Wilcock, P.E., 1992. Flow competence: A criticism of a classic concept. Earth Surface Processes and Landforms, 17: 289-298.

Wolman, M.G., 1954. A method of sampling coarse bed material. American Geophysical Union, Transactions, 35: 951-956. 